SJîñn Jurnal

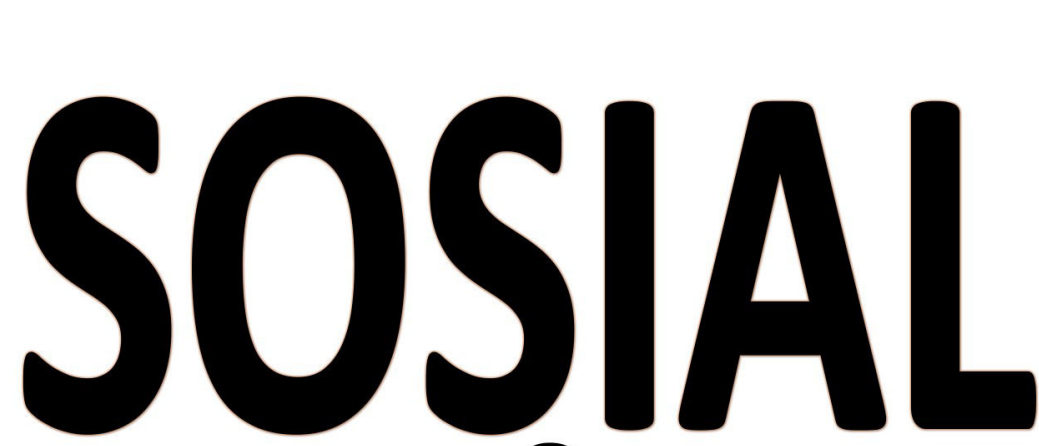

P-ISSN: 2356-1459 E-ISSN: 2654-9050 Vol. 7 No. 5 (2020)
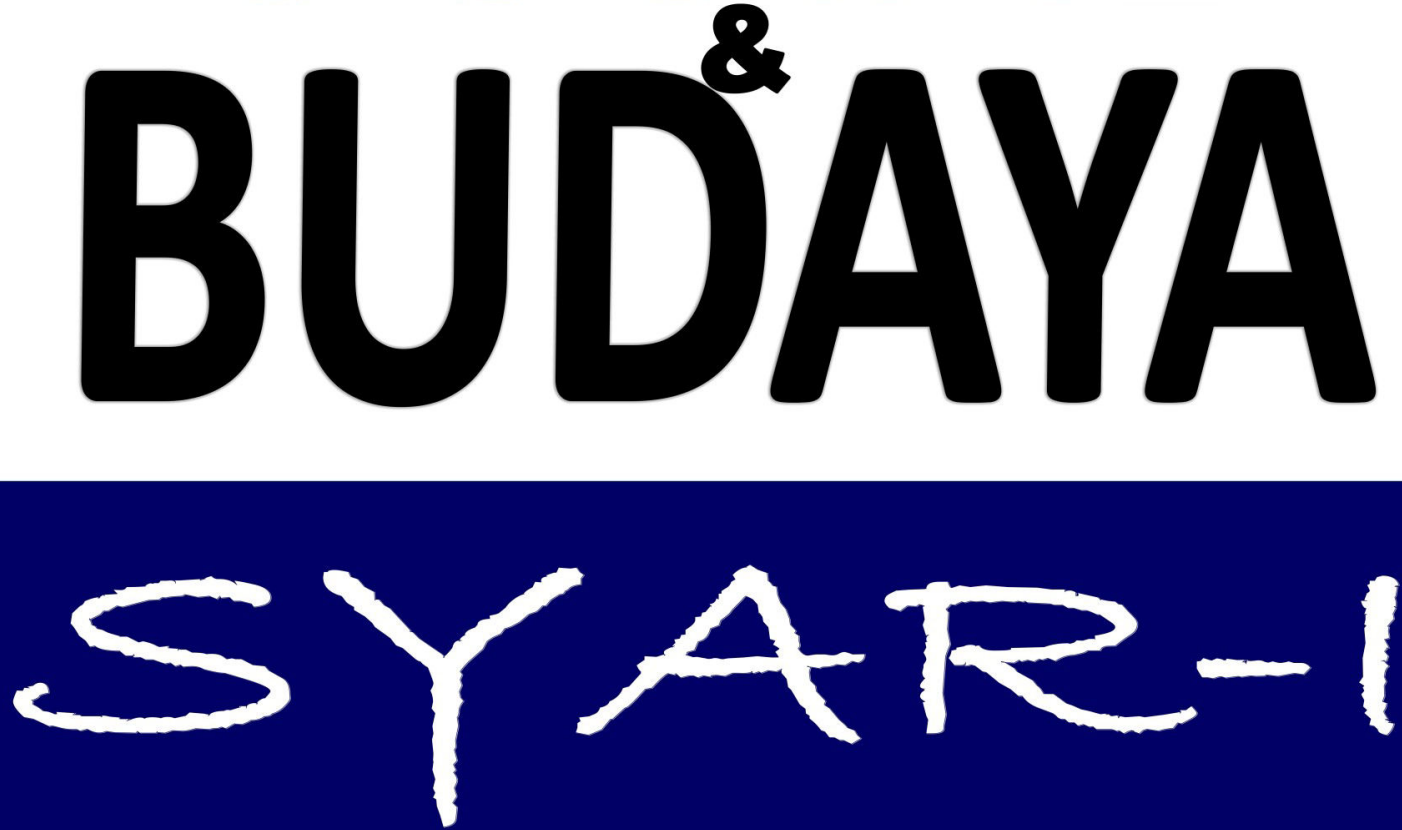

Dampak Covid-19 pada Pendidikan di Indonesia: Sekolah, Keterampilan, dan Proses Pembelajaran Rizqon Halal Syah Aji

Peran Preventif Pemimpin Dalam Pencegahan Penyebaran COVID-19; Strategi Syaykh Al-Zaytun Di Ma'had Al-Zaytun dan Kontribusinya Terhadap Masyarakat Sekitar Imam Prawoto, Siti Ngainnur Rohmah, Fitri Rachmiati Sunarya

Dari Jabariyah, ke Qadariyah, hingga Islam Progresif: Respons Muslim atas Pandemi COVID-19 di Indonesia Nur Hidayah

Transparansi Kebijakan Publik Sebagai Strategi Nasional Dalam Menanggulangi Pandemi Covid-19 Afni Regita Cahyani Muis

Peran Majelis Ulama Indonesia Dalam Mitigasi Pandemi Covid-19;

(Tinjauan Tindakan Sosial dan Dominasi Kekuasaan Max Weber)

Muhamad Agus Mushodiq, Ali Imron

Optimalisasi Upaya Pemerintah Dalam Mengatasi Pandemi Covid 19 Sebagai Bentuk Pemenuhan Hak Warga Negara

Bima Jati, Gilang Rizki Aji Putra

Pandangan Keagamaan Majelis Ulama Indonesia Kabupaten Bogor Terkait Kewajlban Menjaga Diri, Pelaksanaan Shalat Jumat dan Pengurusan Mayit Dalam Situasi Darurat Penyebaran Covid-19 Ahmad Mukri Aji 


\title{
Transparansi Kebijakan Publik Sebagai Strategi Nasional Dalam Menanggulangi Pandemi Covid-19*
}

\author{
Afni Regita Cahyani Muis ${ }^{1}$ \\ Universitas Darussalam Gontor, Ponorogo Indonesia \\ doi $\underline{10.15408 / \text { sjsbs.v7i5.15317 }}$
}

\begin{abstract}
The world is confronted with the COVID-19 pandemic which devastated social activities, the economic sector, politics, and even education. Countries that are threatened by the effects of the COVID-19 pandemic are making various efforts to tackle the outbreak of the deadly virus. The concept of government transparency plays a key role in providing effective decision making for public policy outputs in rapid response to COVID-19 response. Transparency Analysis in this research is public policy in various countries, such as China, South Korea, Taiwan, Vietnam, and Canada, which have successfully applied the concept of transparency to realize a system of good governance. This research aims to be lessons from other countries for national strategies, especially Indonesia in tackling the COVID-19 Pandemic. This research method is a comparative study with learning experience as a media analysis with a literature review.
\end{abstract}

Keywords: Transparency, Public Policy, National Strategy, Pandemic, COVID-19

\begin{abstract}
Abstrak
Dunia sedang diperhadapkan dengan pandemi COVID-19 yang meluluhlantakkan aktivitas sosial, sektor ekonomi, politik, bahkan pendidikan. Negara-negara yang terancam terkena dampak pandemi COVID-19 melakukan berbagai upaya untuk menanggulangi wabah dari virus mematikan tersebut. Konsep transparansi pemerintah memainkan peran kunci dalam memberikan decision making yang efektif bagi output kebijakan publik dalam aksi cepat tanggap penanggulangan COVID-19. Analisis Transparansi dalam penelitian ini adalah kebijakan publik di berbagai negara, seperti Tiongkok, Korea Selatan, Taiwan, Vietnam, dan Kanada yang berhasil menerapkan konsep transparansi untuk mewujudkan sistem good governance. Penelitian ini bertujuan menjadi lessons dari negara lain bagi strategi nasional, khususnya Indonesia dalam menanggulangi Pandemi COVID-19. Metode penelitian ini merupakan studi komparasi dengan learning experience sebagai media analisis dengan kajian literatur.
\end{abstract}

Kata Kunci: Transparansi, Kebijakan Publik, Strategi Nasional, Pandemi, COVID-19

* Diterima: 17 Maret 2020, Revisi: 20 Maret 2020, Diterbitkan 17 Mei 2020.

1 Afni Regita Cahyani Muis adalah Dosen Program Studi Hubungan Internasional, Fakultas Humaniora, Universitas Darussalam Gontor. Email: afniregita@unida.gontor.ac.id. 


\section{Pendahuluan}

Pandemi merupakan penyebaran suatu penyakit atau wabah yang bergerak melintas ke teritorial negara-negara dan merupakan skala besar dari epidemi. Black Death, Flu Spanyol, Flu Asia, Flu Hongkong, HIV/AIDS, Cacar, kolera, Demam Berdarah, Severe Acute Respiratory Syndrome (SARS), Middle East Respiratory Syndrome (MERS), Avian Influenza (H7N9), Flu Babi (H1N1), Ebola, Zika, merupakan deretan kasus akibat virus yang pernah menyerang sepanjang sejarah kasus epidemi dan pandemi di dunia. Di tahun 2020, lebih dari 160 negara di dunia luluhlantah karena dampak pandemi COVID-19, yakni berpengaruh signifikan terhadap aktivitas perekonomian, pendidikan, bahkan dalam sosial masyarakat.

Dilematis berbagai negara dunia dalam menanggulangi Pandemi Corona Virus Disease-19 (COVID-19) telah menjadi perhatian antara satu negara dengan negara yang lain. Transparansi pemerintah menjadi tuntunan di tengah wabah yang menyerang sistem inti pernapasan manusia ini. Kebijakan pemerintah dalam upaya menanggulangi COVID-19 sebagai upaya untuk perlindungan masyarakat sipil dari pihak eksternal yang sewaktu-waktu dapat menjadi bom waktu dan mengancam keselamatan masyarakat. Kebijakan negara dalam memberikan layanan kesehatan yang memadai menjadi strategi nasional dalam menanggulangi COVID-19. Menariknya, tidak semua negara memberlakukan kebijakan yang sama. Hal ini dikarenakan karena kapasitas setiap wilayah dalam satu negara saja bisa berbeda.

Urgensi penulisan ini adalah bahwa ketika tidak seimbangnya kapasitas suatu daerah atau negara dalam memenuhi fasilitas yang memadai, maka transparansi pemerintah adalah kunci bagi semua negara dalam menyatukan suara untuk menanggulangi pandemi COVID-19. Tujuan dari penelitian ini adalah memberikan pemahaman bahwa dengan transparansi pemerintah demi menanggulangi pandemi COVID-19 adalah hal yang krusial untuk diterapkan negara, karena bagaimanapun masyarakat memiliki hak untuk mendapat rasa aman di dalam negaranya. Penelitian diharapkan dapat bermanfaat sebagai rujukan ilmiah nasional dengan metode learning experience sebagai rekomendasi dalam menanggulangi pandemi COVID-10.

\section{Good Governance: Transparansi}

Good governance merupakan hak yang bersifat fundamental bagi warga negara terhadap pemerintahnya. Good governance yang disalurkan melalui pelayanan untuk masyarakat memiliki struktur dasar konstitusi negara. Beberapa poin penting dari perolehan hak atas good governance adalah hak untuk menginformasikan, kebebasan pers, perlindungan lingkungan. United Nations Development Programme mengklasifikan good governance yang terdiri dari: partisipasi, transparansi, responsif, akuntabilitas, legitimasi, kerjasama, peraturan hukum, orientasi konsensus. Kesetaraan, efektivitas dan efisiensi, visi strategi, kebenaran sumber daya, kesehatan ekologis, pemberdayaan, dan landasan spasial dalam masyarakat. Good governance bersumber pada indikatorindikator sebagai berikut: 1) Menaruh seluruh aktivitas berdasarkan dorongan permintaan, 2) Pengembangan aktivitas berorientasi masyarakat sentis dan 
mengusahakan partisipasi masyarakat, 3) Memastikan transparansi dalam administrasi dan proses membuat keputusan, 4) Meningkatkan efisiensi dan efektivitas dalam layanan pokok, 5) Memastikan kesetaraan dalam proses distribusi manfaat kepada yang membutuhkan. ${ }^{2}$

Pemerintah sebagai memanajemen sumber daya memerlukan transparansi yang memiliki sifat keterbukaan, akuntabilitas dan kebenaran. Pemerintah berkewajiban memberikan informasi kepada masyarakat. Dalam hal ini adalah bagaimana warga negara meminta pertanggungjawaban (akuntabilitas) pemerintah dalam memberikan pelayanan untuk masyarakat. Transparansi dan akuntabilitas adalah konsep inti dari good governance.

Transparansi menjelaskan mengenai aturan, rencana, proses, dan implementasi untuk mengetahui mengapa, bagaimana, apa, dan berapa banyak. Transparansi memastikan bahwa pejabat publik, pegawai sipil, manajer, anggota dewan, pengusaha, agar dapat melaporkan aktivitasnya sehingga masyarakat dapat meminta pertanggungjawaban pemangku kepentingan. Kemudian, konsep akuntabilitas digunakan untuk menjawab kewajiban pemerintah, menyediakan informasi tentang keputusan dan bagaimana implementasi dapat disuguhkan kepada masyarakat dan lembaga-lembaga akuntabilitas yang memberikan pengawasan, menyarankan masyarakat atau institusi untuk bertanggungjawab atas akuntabilitas yang dapat memberikan sanksi kepada pihak yang bersalah atau memperbaiki perilaku yang bertentangan. ${ }^{3}$

\section{Konsep Transparansi dalam Kebijakan Publik}

Konsep transparansi adalah bagian dari prinsip good governance. Didalam sistem pemerintahan, konsep transparansi digunakan sebagai subjek analisis pada bidang teori negosiasi, keamanan internasional, dan efektivitas suatu rezim. ${ }^{4}$ Dalam hal ini, transparansi menjadi sisi afektif bagi pemerintah dalam mengeluarkan kebijakan publik, utamanya dalam mengidentifikasi seberapa efektif suatu kebijakan yang dikeluarkan pemerintah terhadap aplikasinya ke dalam masyarakat. Transparansi dalam kebijakan publik didefinisikan sebagai upaya pemerintah dalam memberikan informasi sosial, politik, ekonomi, segala bidang yang melibatkan masyarakat dalam memberikan ketersediaan, kepercayaan, dan aksesibilitas informasi antar pemangku kepentingan.

Pada tahun 2009, Presiden Obama juga menyatakan bahwa transparansi mendorong akuntabilitas dan menyediakan informasi kepada masyarakat mengenai

2 G. Palanithurai. (2005). Good Governance at Grassroots. The Indian Journal of Political Science, 66(2) hlm. 289-312. Diakses dari www.jstor.org/stable/41856129

3 USAID. (2013). Transparency and Accountability: Regional Agricultural Trade Environment

(RATE) Summary. USAID Regional Development Mission for Asia. Diakses dari https://www.usaid.gov/sites/default/files/documents/1861/Transparency and Accountability.pdf

${ }^{4}$ Bauhr and Grimes. (2012). What is Government Transparency? New Measures and Relevance for Quality of Government. Diakses dari University of Gothenburg, https://qog.pol.gu.se/digitalAssets/1418/1418047 2012 16 bauhr_grimes.pdf 
apa yang sedang dilakukan oleh pemerintah mereka. Transparansi akan menguatkan peran demokrasi dan menggalakkan efisiensi dan efektivitas dalam pemerintahan. ${ }^{5}$

Transparansi dalam kebijakan merupakan powerful tool dalam menginformasikan kebijakan pilihan yang ditujukan untuk peningkatan produk dan bagaimana implementasinya. Masyarakat, baik dalam kelompok maupun pribadi dapat mendorong perbaikan kinerja sistem transparansi dengan melibatkan konsumen, pekerja, dan warga. Mereka dapat berperan sebagai perantara dalam menginterpretasi data yang diberikan dan dapat mendorong perbaikan kualitas informasi di bidang politik. Dalam hal ini, kesadaran masyarakat akan pemenuhan janji atau tidaknya dari sebuah kebijakan digunakan untuk menciptakan kewaspadaan dan dinamika politik dalam mendukung penguatan transparansi. ${ }^{6}$

Dalam rangka untuk menciptakan efektivitas transparansi dalam kebijakan sosial diperlukan transparansi sebagai watak dan penengah dari kesenjangan informasi sehingga transparansi dapat berkontribusi secara substansial untuk resiko publik atau kegagalan dalam pelayanan masyarakat. Transparansi tidak akan berfungsi jika masyarakat tidak terlibat dalam upaya untuk measure improvement, maka efektivitas transparansi juga perlu didukung dengan praktik komunikasi publik. Kemudian, masyarakat sebagai pengguna informasi memiliki keinginan, kapasitas, alat kognitif untuk mengupayakan pilihan mereka, sehingga jika informasi yang tidak memiliki nilai, maka tidak akan menjadi pilihan yang baik untuk proses transparansi. Mengungkapan informasi dapat mengurangi resiko dan meningkatkan kinerja transparansi kebijakan. Jika transparansi gagal seperti pada kebijakan dalam sistem pendidikan di sekolah dan layanan kesehatan, maka kepercayaan masyarakat akan hilang. Transparansi kebijakan yang efektif dengan menerapkan prinsip-prinsip sebagai berikut: ${ }^{7}$

1). Menyediakan informasi yang dapat secara mudah digunakan masyarakat.

2) Memperkuat kelompok pengguna yang digunakan untuk sistem transparansi yang berkelanjutan. Contohnya adalah ketika kelompok advokasi, analis, politisi, dan pemangku kepentingan yang merepresentasikan kepentingan masyarakat.

3) Membantu memahami bagaimana ketika pilihan dalam kebijakan tersebut berubah. Dalam hal ini, transparansi kebijakan akan gagal jika pemangku kepentingan tidak dapat membedakan pilihan masyarakat sipil dengan alasan mengapa mereka mengubah atau tidak dapat memberi pilihan tersebut. Kesuksesan transparansi tergantung dengan memahami tipe-tipe masalah yang tidak dapat secara sukses hanya dengan pengungkapan informasi.

${ }^{5}$ Steven Aftergood. (2019). Transparency vs. Good Government. Diakses tanggal 28 Maret 2020, dari https://fas.org/blogs/secrecy/2019/11/transparency-vs-good-govt/

${ }^{6}$ Fung, Graham, Wil, Fagotto. (2007). Transparency Policies: Two Possible Futures. Diakses dari Harvard

University,

https://www.hks.harvard.edu/sites/default/files/centers/taubman/files/transparency new.pdf

${ }^{7}$ Ibid 
4) Merancang kegunaan manfaat mengungkapkan informasi. Kebijakan harus berupaya menghasilkan informasi yang memperkuat insentif ekonomi, politik, dan peraturan dalam disclosers environment.

5) Merancang parameter yang sesuai dengan tujuan kebijakan dan memungkinkan masyarakat agar dengan mudah membandingkan produk atau layanan.

6) Kebijakan akan lebih efektif jika dapat mencocokkan isi dan format informasi dengan tingkat perhatian dan pemahaman masyarakat. Hal ini didukung dengan ketersediaan fakta lapangan yang masif dengan menggunakan data-data metrik.

7) Sistem transparansi yang menggabungkan fungsi analisis dan feedback akan melakukan analisis secara berkala, melihat feedback, dan melakukan revisi kebijakan yang beradaptasi dengan perubahan kondisi.

8) Memberikan sanksi bagi yang melanggar substansi sebagai upaya memperkuat penegakan hukum.

9) Ketika transparansi tidak cukup untuk menghasilkan output yang efektif, transparansi dapat dirancang bersama dengan kebijakan pemerintah yang lain.

Bagaimanapun keterbukaan publik adalah hak asasi bagi masyarakat, seperti memperoleh informasi mengenai proses kebijakan publik, anggaran, pengawasan, dan evaluasinya, sehingga diharapkan kinerja pemerintah sesuai dengan harapan masyarakat dan bagaimana keberpihakan pemerintah terhadap pelayanan publik. Disamping itu, transparansi dapat membentuk check and balance terhadap kontrol sosial. ${ }^{8}$

\section{Penerapan Transparansi dalam Pelayanan Publik sebagai Strategi Nasional}

Transparansi kini menjadi hal yang urgensi bagi perkembangan politik dan pemerintahan di dunia. Tidak hanya untuk pelayanan masyarakat, tetapi transparansi juga berpengaruh terhadap kepercayaan suatu negara dengan negara lain dalam kerangka kerja sama. Menurut OMBUDSMAN, beberapa strategi penerapan transparansi dalam pelayanan masyarakat, 1) Mengidentifikasi peran masyarakat agar mendorong partisipasi publik untuk meningkatkan kualitas pelayanan publik, 2) Meningkatkan peran lembaga pengawas eksternal dalam mengawasi pelayanan publik, 3) Komitmen pemerintah dengan keterbukaan publik, sehingga masyarakat memperoleh informasi dengan mudah, mengawal proses pelayanan publik, dan mengevaluasi pelayanan publik yang kurang optimal. ${ }^{9}$ Ketersediaan infrastruktur kesehatan dari segi kebijakan publik yang belum memadai merupakan inisiasi

${ }^{8}$ Maya Septiani. (2020). Strategi Mewujudkan Transparansi dan Partisipasi dalam Pelayanan Publik. OMBUDSMAN, Diakses dari https://ombudsman.go.id/artikel/r/artikel--strategi-mewujudkantransparansi-dan-partisipasi-dalam-pelayanan-publik

9 Ibid 
pemerintah pusat dan swasta agar melibatkan swasta, yayasan, kelompok sukarelawan, dan kelompok profesional. ${ }^{10}$

Dalam membentuk strategi nasional, fungsi transparansi harus kuat, karena kepercayaan masyarakat pada kewenangan pemerintah dapat meningkatkan akuntabilitas dan fungsi dari kewenangan pemerintah itu. Strategi nasional juga memiliki tujuan dalam meningkatkan transparansi pada mekanisme dan aturan pengambilan keputusan, akses pelayanan sipil, penerimaan dan pengeluaran anggaran negara, pembiayaan partai politik, pengadaan pemerintah, privatisasi, fungsi otoritas negara, kota madya, dan wilayah lainnya. ${ }^{11}$

Penerapan transparansi dalam kebijakan publik sebagai strategi nasional dilakukan berbagai negara dalam menghadapi Pandemi COVID-19. Tindakan preventif dan penanggulangan pandemi COVID-19 dilakukan sebagai upaya dalam menekan angka penularan signifikan kepada masyarakat luas. Hal ini tidak hanya berdampak pada aspek sosial, tetapi juga berdampak negatif pada sektor ekonomi. Strategi nasional sebagai aspek politik dituntut berperan dalam mewujudkan transparansi demi meminimalisir kasus pandemic COVID-19. Pemerintah di berbagai negara memiliki metode dalam menerapkan kebijakan publik yang efektif dan efisien. Namun, rata-rata kunci dari keberhasilan pemerintah dunia adalah menerapkan konsep transparansi dalam pelayanan publiknya.

Urgensi konsep transparansi dalam pelayanan kesehatan bagi publik dan bagaimana pemerintah pusat dan daerah saling berintegrasi memberikan arahan dalam memfasilitasi kebutuhan ekonomi dan logistik (termasuk pangan). Namun, tidak semua negara berhasil dalam menentukan kebijakan publik sebagai strategi nasional untuk menghadapi pandemi COVID-19. Antisipasi lalu lalang masyarakat dalam mencegah penularan juga dilakukan dengan karantina wilayah atau lockdown, namun istilah lockdown mengalami penyempitan definisi sehingga menciptakan miskomunikasi antara pemerintah pusat, daerah, dan masyarakat. Adanya pertentangan antara kebutuhan dan kepentingan di sektor lain disebut sebagai enggannya keterbukaan pemerintah dalam memberikan informasi. Maka timbulah ketidakpercayaan masyarakat pada kewenangan pemerintah.

\section{Tiongkok}

Wabah pandemi COVID-19 pertama kali dikonfirmasi terjadi di Wuhan, Tiongkok. Berhembusnya virus yang bermutasi pada kondisi saat ini disebut-sebut sudah terdengar sejak November 2019 oleh seorang pakar kesehatan Tiongkok. Penyebarannya ke negara lain mulai merebak sejak awal tahun 2020. Sebagai negara yang terkenal dengan jumlah tenaga kerja yang besar dan kemampuan bekerja secara

${ }^{10}$ A National Strategy on AIDS. (1989). Issues in Science and Technology Volume 5(3) hlm. 52-59. Diakses dari www.jstor.org/stable/43309389

${ }^{11}$ UNODC. (2007). National Strategy on Increasing Transparency and Anti-Corruption 2007-2011. Diakses dari https://www.unodc.org/documents/corruption/Best\%20Practices/Azerbaijan\%2020072011Strategy $\% 20$ Expl\%20Note-Eng.pdf 
cepat, ambisi Tiongkok dalam pengembangan dan pekerja konstruksi dikenal unggul dibanding negara lain. Dalam menangani pandemi COVID-19, pemerintah Tiongkok mengerahkan sumber dayanya membangun infrastruktur kesehatan secara agresif. Pembangunan Rumah Sakit Huoshenshan di Wuhan yang dibangun dalam waktu 8 hari, Rumah Sakit Xiaotangshan di Beijing dalam waktu 7 hari, Rumah Sakit Leishenshan di Wuhan dalam waktu 7 hari. ${ }^{12}$ Kecepatan pembangunan rumah sakit tersebut disinyalir sebagai learning experience saat membangun rumah sakit khusus SARS, Xiaotangshan di Beijing pada tahun 2003.13

Tiongkok sebagai negara dengan sistem ke pemerintahan sosialis sukses memperlihatkan bagaimana kemajuan ekonomi mereka berkembang pesat. Hal ini tidak terlepas dari sistem good governance ala Tiongkok yang menunjukkaan efektivitas, efisiensi, dan responsif dalam institusi publik tanpa embel-embel demokrasi. Di Rezim Xi Jinping, sistem good governance diorientasikan pada perkembangan ekonomi politik dengan lingkungan sosial. Xi Jinping menanamkan retorika nasional 'mimpi orang Tiongkok' yang fokus pada wealth and power melalui intervensi pemerintah. Xi Jinping menjunjung tinggi urgensi supermasi hukum, menggunakan atribut inti dari bentuk pemerintahan sosialis, meningkatkan posisi rakyat sebagai aktor utama dengan karakteristik ala Tiongkok sehingga tidak menuruti hukum dan aturan kapitalisme. ${ }^{14}$

Untuk menunjukkan respon global tentang penanggulangan COVID-19 di Tiongkok, WHO-China Joint Mission on Coronavirus Disease 2019 merekomendasikan 5 area utama: ${ }^{15}$

1) Sebagai negara dengan ambisi, gesit, dan agresif dalam penanggulangan virus sepanjang sejarah. Strategi yang dilakukan Tiongkok adalah pendekatan nasional yang mmpromosikan pemantauan suhu, penggunaan masker, dan mencuci tangan. Ketika wabah berkembang, Tiongkok mengambil ilmu pengetahuan dan pendekatan berbasis resiko untuk menyesuaikan proses pengendalian. Langkah-langkah tersebut disesuaikan dengan konteks provinsi, kabupaten, bahkan komunitas, kapasitas pengaturan, dan sifat penularan virus COVID-19 di Tiongkok. Konsentrasi Tiongkok adalah meningkatkan kecepatan mendeteksi kasus, isolasi dan perawatan dini. Hal ini didukung dengan inovasi dan penggunaan teknologi canggih secara agresif, beralih ke online medical

12 Ahmad Naufal Dzulfaroh. (2020). Mengenal Leishenshan, Rumah Sakit Kedua Khusus Virus Corona. Diakses dari https://www.kompas.com/tren/read/2020/02/06/104500265/mengenal-leishenshanrumah-sakit-kedua-khusus-virus-corona?page=2

${ }^{13}$ Hilda Alexander. (2020). Sekali Lagi, Ini Rahasia China Bangun Rumah Sakit Corona Secepat Kilat. Diakses dari https://properti.kompas.com/read/2020/02/04/063000521/sekali-lagi-ini-rahasia-chinabangun-rumah-sakit-corona-secepat-kilat?page=all

${ }^{14}$ Hans Nibshan Seesaghur. (2015) Good Governance with Chinese Characteristics: A Perspective of China's Socialist Model. Journal of Public Administration and Governance 2015, Volume 5 Nomor 3. DOI: 10.5296/ jpag.v5i3.8028

${ }^{15}$ World Health Organization. (2020). Report of the WHO-China Joint Mission on Coronavirus Disease 2019 (COVID-19). Diakses dari https://www.who.int/docs/default-source/coronaviruse/who-chinajoint-mission-on-covid-19-final-report.pdf 
platform untuk perawatan rutin dan sekolah sampai menggunakan platform $5 \mathrm{G}$ untuk mendukung operasi respons pedesaan.

2) Pencapaian Tiongkok yang luar biasa dimungkinkan karena besarnya komitmen masyarakat Tiongkok melakukan tindakan kolektif dalam menghadapi ancaman bersama. Level masyarakat terlaksana dengan baik atas solidaritas skala provinsi dan kota dalam mendukung sebagian besar populasi dan masyarakat yang rentan. Disamping itu, Gubernur dan Walikota mengirim beribu-ribu tenaga kesehatan dan menyediakan APD vital ke Provinsi Hubei dan Kota Wuhan.

3) Misi gabungan antara WHO dan Tiongkok sebagai jawaban atas respons global dalam menekan kekuatan infeksi COVID-19 dalam melawan penyebaran internasional. Hal ini dilakukan dengan peningkatan kapasitas pada infrastruktur kesehatan dan meningkatkan kolaboratif antara pengetahuan dan alat kesehatan.

4) Melakukan secara tepat dengan pendekatan berbasis ilmu pengetahuan, riskinformed, dan secara bertahap memiliki kesiapan yang jelas atas kebutuhan yang diperlukan dalam penanggulangan COVID-19 sebagai elemen kunci strategi penahanan.

Strategi nasional Tiongkok dengan menggandeng WHO mendapat respons global, karena COVID-19 sangat menular, menyebar sangat cepat, dan berdampak signifikan pada aktivitas kesehatan, ekonomi, dan sosial masyarakat. COVID-19 merupakan hasil mutasi virus yang berkembang dan dapat beradaptasi pada iklim dunia saat ini. Disamping itu, banyaknya masyarakat global yang belum siap secara mindset dan material. Pemerintah Tiongkok dalam menggandeng organisasi kesehatan internasional merupakan upaya dalam melaksanakan transparansi penanggulangan pandemi COVID-19, baik rencana dan implementasinya. Transparansi strategi nasional Tiongkok juga ditujukan pada masyarakat global dan memperoleh kepercayaan atas kapabilitas yang dimilikinya.

\section{Korea Selatan}

Korea Selatan menjadi negara kedua terbesar di dunia atas kasus penularan pandemi COVID-19 yang terjadi dalam kurun waktu 3 minggu. Penanggulangan Pandemi COVID-19, Korea Selatan menekan angka penularan virus melalui tindakan transparansi pemerintah, teknologi terbaru, dan pendekatan yang bertanggungjawab oleh institusi dan warga negara. ${ }^{16}$ Penerapan transparansi dan keterbukaan informasi pemerintah Korea Selatan pada publik mengenai situasi yang terjadi. Otoritas kesehatan Korea Selatan melacak dan mempublikasikan masyarakat yang positif terjangkit COVID-19 sehingga memungkinkan warganya untuk memverifikasi jika melakukan kontak dengan orang yang terinfeksi. Pemerintah juga mengambil tindakan-tindakan dalam mengatasi kekurangan masker dan produk kebersihan, menindak penimbun

${ }^{16}$ Andres Sanchez Brau. (2020). Commitment, Transparency Pay Off as South Korea Limits COVID19 Spread. Diakses dari https://www.euractiv.com/section/coronavirus/news/commitment-transparencypay-off-as-south-korea-limits-covid-19-spread/ 
ilegal, melarang ekspor masker, dan mengambil kontrol penuhi atas distribusi dan logistik agar meningkatkan kecepatan produksi lokal dan rasio distribusi. ${ }^{17}$

Keberhasilan Korea Selatan dalam menangani krisis COVID-19 merupakan hasil dari pengelolaan pemerintah dalam menegaskan transparansi dan komunikasi terbuka, kerja sama publik dan pihak swasta, penyebaran, tindakan kesehatan masyarakat berbasis bukti, dan penggunaan teknologi dan data yang inovatif. Tindakan transparansi dan komunikasi pemerintah Korea Selatan membantu dalam menghilangkan rasa takut dan mencegah kepanikan. Pemerintah membangun informasi yang masif kepada publik dan melakukan kampanye tentang kebersihan diri dan social distancing. Pemerintah melakukan menginformasikan kepada pers 2 kali sehari, memperbaharui informasi online secara terus-menerus, dan mengirim pesan teks yang ditargetkan. Kemudian, meluncurkan pengujian secara besar-besaran dan informasi tentang hasilnya sehingga ketakutan dan kesalahan informasi dapat diminimalisir. Pemerintah membatasi pertemuan berskala besar, menutup sekolah dan pusat penitipan anak, dan meminta pengusaha untuk menawarkan pengaturan kerja yang fleksibel. Kota Daegu dan 3 kabupaten di Gyeongsang Utara ditetapkan sebagai zona perawatan khusus dan kemudian dinyatakan sebagai daerah bencana sehingga masyarakat dapat memperoleh manfaat dari sumber daya tambahan dan profesionalitas kesehatan. ${ }^{18}$

Untuk memperkuat tindakan penanggulangan, Korea Selatan menggunakan Big Data, seperti GPS Tracking data dari telefon seluler dan mobil, transaksi kartu kredit, riwayat perjalanan, rekaman CCTV, dan artificial intelligence untuk mengidentifikasi kasus high-priority, dan melacak rute individu yang terinfeksi. Penggunaan aplikasi smartphone juga dikerahkan untuk turis internasional yang masuk ke Korea Selatan dan wajib menjalani pemantauan atau isolasi diri selama 14. Rumah sakit juga memperkenalkan diagnosis jarak jauh untuk pasien dengan gejala ringan dan membebaskan tenaga medis profesional untuk menjalankan teknis kesehatan pada pasien yang memiliki gejala serius. Pemerintah Korea Selatan juga bekerja sama dengan pihak swasta, yaitu perusahaan ICT ternama di Korea Selatan dengan membangun Global Epidemic Prevention Platform (GEPP). Keberhasilan Korea Selatan ini merujuk pada pengalamannya saat menanggulangi wabah MERS. ${ }^{19}$

Langkah-langkah agresif pemerintah Korea Selatan dalam menanggulangi pandemi COVID-19 dengan sistem pemerintahan demokrasi membuktikan fungsi sistem good governance yang solid. Keterbukaan informasi pemerintah kepada masyarakatnya yang tidak hanya memberi himbauan, tetapi juga didukung dengan infrastruktur kesehatan yang memadai. Fungsi pemerintah memobilisasi alat-alat kesehatan adalah dengan menjadi pusat distribusi kepada orang-orang prioritas, utamanya tenaga medis sehingga fasilitas-fasilitas medis seperti APD terpenuhi.

\footnotetext{
17 Jenny Town. (2020). South Korea's Pandemic Response. Diakses dari https://www.stimson.org/2020/south-koreas-pandemic-response/

${ }^{18}$ Chung dan Soh. (2020). Korea's response to COVID-19: Early Lessons in Tackling the Pandemic. Diakses dari https://blogs.worldbank.org/eastasiapacific/koreas-response-covid-19-early-lessons-tacklingpandemic 


\section{Taiwan}

Negara yang dijuluki Republik Tiongkok ini berada pada letak geografis yang sangat dekat dengan Tiongkok. Berdasarkan data dari John Hopkins Coronavirus COVID19 Global Case map, sampai pada 3 Maret 2020, kasus COVID-19 yang terjadi di Taiwan hanya ada 42 kasus dan satu yang meninggal. Hal ini bertolak belakang dengan Tiongkok yang mencapai lebih dari 80.000 kasus dengan angka kematian lebih dari 2.900. Pemerintah Taiwan mendirikan National Health Command Center (NHCC) setelah SARS dan layanan kesehatan tersebut menjadi disaster management center yang fokus pada respons wabah besar dan bertindak sebagai titik komando operasional secara langsung. Pakar kebijakan kesehatan Stanford University mencatat bahwa Taiwan mengintegrasikan database asuransi kesehatan nasional dengan database imigrasi dan bea cukai untuk analisis big data dalam mengidentifikasi kasus yang menghasilkan peringatan selama kunjungan klinis berdasarkan riwayat perjalanan dan gejala klinis. Pemerintah Taiwan juga menggunakan pemindaian $Q R$ Code dan pelaporan online riwayat perjalanan, dan gejala kesehatan untuk klarifikasi resiko infeksi dalam 14 hari terakhir. Negara turut memfasilitasi hotline bebas pulsa untuk melaporkan gejala yang mencurigakan. ${ }^{20}$

Transparansi yang dilakukan oleh Pemerintah Taiwan adalah upaya tindakan preventif dan penanggulangan sedini mungkin. Seperti halnya Korea Selatan, fungsi pemerintah mengambil peran penting sebagai pusat distribusi dalam mengamankan APD demi memenuhi kebutuhan medis. Keterbukaan informasi dan mobilisasi pemerintah dan upaya pemerintah mendorong partisipasi masyarakat menjadi kunci bagi keberhasilan Taiwan dalam menekan penyebaran COVID-19 di negaranya.

\section{Vietnam}

Vietnam adalah negara berkembang yang memiliki tingkat kemiskinan yang cukup tinggi. Keterbatasan Vietnam dalam memenuhi infrastruktur medis yang canggih tidak menyurutkan tekad Vietnam dalam menekan angka penularan pandemi COVID19 di negaranya. Tindakan cepat pemerintah Vietnam dalam memberikan informasi dan kekuatan memobilisasi areal umum yang memiliki risiko tinggi penularan COVID-19 berperan kunci dalam penanggulangan pandemi COVID-19. Hal yang menarik adalah bagaimana Vietnam dapat cepat tanggap memberlakukan karantina bagi masyarakat asing, dan areal-areal umum dengan pemberian insentif terhadap kebutuhan mereka, dan menutup wilayah yang terkena dampak paling besar di Vietnam.

Vietnam juga tidak mengadakan program tes masal selayaknya Korea Selatan. Data dari World Economic Forum menunjukkan bahwa sampai akhir Maret 2020, Vietnam tidak memiliki korban jiwa akibat COVID-19. Pergerakan pemerintah Vietnam yang secara agresif menangguhkan penerbangan, menutup sekolah, dan mengkarantina

${ }^{20}$ Beth Duff-Brown. (2020). How Taiwan Used Big Data, Transparency and a Central Command to Protect Its People from Coronavirus. Diakses dari Stanford University https://fsi.stanford.edu/news/howtaiwan-used-big-data-transparency-central-command-protect-its-people-coronavirus 
pendatang baru adalah kunci Vietnam dalam menanggulangi pandemi COVID-19 secara efektif. Dimulai dari awal Februari, Vietnam sudah menutup akses penerbangan dari dan ke Tiongkok, menutup sekolah sampai setelah Tahun Baru Lunar berakhir, 2 minggu kemudian menerapkan karantina wilayah di Provinsi Vinh Phuc, Hanoi Utara. Vietnam diuntungkan sebagai negara dengan partai tunggal yang memiliki sektor keamanan yang besar sehingga layanan publik terorganisir dengan baik. Hal ini berdampak pada decision making yang terlaksana dengan cepat. ${ }^{21}$

\section{Kanada}

Sebagai negara demokrasi yang memperlihatkan sistem good governance dalam menanggulangi pandemi COVID-19, Kanada menekankan penguatan transparansi dan ketersediaan data yang memadai untuk memberi layanan yang efektif kepada masyarakat. Perdana Menteri Justin Trudeau memproyeksikan kerjasama pemerintah pusat dengan pemerintah provinsi untuk meningkatkan sharing data. Walaupun Kanada tidak lebih agresif dibandingkan dengan negara-negara diatas, namun mengingat Kanada berbatasan dengan Amerika Serikat sebagai korban COVID-19 terbesar di dunia saat ini, transparansi sangat mungkin dilakukan. Tidak hanya memenuhi fasilitas medis, namun pemerintah Kanada berupaya membuat masyarakatnya untuk tetap tenang di rumah, seperti menjamin pasokan pangan, kebutuhan bisnis, kemudahan akses informasi melalui platform, menutup sekolah, dan memberikan akses informasi bagi anak-anak tentang tindakan preventif pandemi COVID-19. Eksistensi Jason Trudeau dalam menyampaikan rencana tindakan pemerintah adalah upaya bagaimana secara psikologis dapat menenangkan masyarakatkan untuk tinggal di rumah secara aman melalui transparansi pemerintah.

\section{Urgensi Cepat Tanggap Pemerintah}

Tiongkok, Korea Selatan, Taiwan, Vietnam, Kanada adalah negara-negara yang berada dalam jajaran yang berhasil menanggulangi pandemi COVID-19. Menariknya adalah negara-negara tersebut memiliki sistem pemerintahan yang berbeda-beda. Kunci dari kesuksesan negara-negara tersebut transparansi pemerintah, baik akses informasi yang baik maupun mobilisasi pemerintah. Pada nyatanya, transparansi pemerintah tidak selalu berada dalam sistem pemerintahan yang demokratis. Melihat bagaimana Tiongkok dan Vietnam yang dikuasai oleh partai tunggal memiliki peranan besar dalam mengambil keputusan secara cepat. Sebaliknya, Amerika Serikat sebagai negara 'kiblat' demokrasi lamban merespons kasus ini. Upaya transparansi yang dilakukan Presiden Donald Trump pada publik tidak efektif berjalan karena tidak dibarengi dengan keterbukaan informasi dan partisipasi masyarakat dalam pergerakan pemerintah.

21 Sean Fleming. (2020). Viet Nam Shows How You Can Contain COVID-19 with Limited Resources. Diakses dari https://www.weforum.org/agenda/2020/03/vietnam-contain-covid-19-limited$\underline{\text { resources/ }}$ 
Aksi cepat tanggap pemerintah dalam juga dilakukan dengan menghimbau social atau physical distancing pada seluruh masyarakat. Keterlibatan masyarakat berperan penting untuk mencegah penularan COVID-19. Namun, sampai saat ini masih banyak masyarakat yang mengindahkan, utamanya karena faktor ekonomi, bahkan faktor sosial. Disinilah peran pemerintah pusat dan daerah agar secara terbuka memberikan informasi yang memadai dan mengerahkan pemangku kepentingan termasuk pihak swasta untuk memberikan fleksibilitas terhadap kerja karyawannya; membatasi gerak masyarakat dengan tetap memberdayakan pedagang-pedagang yang memenuhi kebutuhan masyarakat; menjalankan distribusi logistik; memudahkan akses pelayanan kesehatan bagi Orang Dalam Pemantauan; Pasien Dalam Perawatan, dan Positif; pemerintah sebagai sentra distributor APD; blokade akses penerbangan, baik dari dalam maupun keluar negeri sehingga dapat membatasi wisatawan hilir-mudik secara bebas; menutup fasilitas umum yang memiliki tingkat resiko tinggi, seperti sekolah, dsb. Bahkan menerapkan karantina wilayah bagi daerah yang mengalami resiko penularan tinggi.

Polemik karantina wilayah atau lockdown masih menjadi perdebatan karena di satu sisi dapat memblokade arus investasi dan perdagangan, namun disisi lain diperlukan bagi daerah yang belum memiliki fasilitas medis yang memadai. Kacaubalau akibat lockdown terjadi di India, dimana penerapan ini terjadi terlalu dini dan kurangnya persiapan pemerintah dalam memenuhi pasokan kebutuhan masyarakat. Disamping itu, Italia dan Spanyol sebagai negara dengan jumlah kasus COVID-19 tertinggi di dunia mampu mengurangi jumlah korban sampai 2 kali lipat karena berhasil menerapkan lockdown. Polemik yang masih menjadi perdebatan terjadi di Indonesia. Sampai pada 7 April 2020, Indonesia menjadi negara dengan tingkatan kematian paling tinggi di Asia. Data dari Kementerian Kesehatan dan Gugus Tugas Percepatan Penanganan COVID-19 menunjukkan bahwa sebanyak 221 Pasien meninggal dengan peningkatan 2.738 pasien Positif COVID-19. Kurangnya transparansi pemerintah pusat dalam memberikan data yang valid memutuskan sejumlah pemerintah daerah melakukan lockdown atau karantina wilayahnya secara mandiri. Namun, keputusan ini ditentang pemerintah pusat karena keputusan karantina wilayah merupakan kewenangan pemerintah pusat. Integrasi pemerintah pusat dan daerah yang tidak singkron menyebabkan penyebaran COVID-19 di hampir di seluruh provinsi di Indonesia bergerak dengan cepat. Tidak terkecuali Jakarta sebagai kota yang memiliki jumlah korban COVID-19 di Indonesia yang baru memberlakukan Pembatasan Sosial Berskala Besar (PSBB) yang telah disetujui oleh pemerintah pusat, namun berlaku secara nasional.

PSBB di Indonesia merujuk pada Undang-Undang Nomor 6 Tahun 2018 Pasal 1 Ayat 1 Tentang Karantinan Kesehatan yang menyebutkan bahwa "Pembatasan Sosial Berskala Besar adalah pembatasan kegiatan tertentu penduduk dalam suatu wilayah yang diduga terinfeksi penyakit dan/atau terkontaminasi sedemikian rupa untuk mencegah kemungkinan penyebaran penyakit atau kontaminasi." PSBB setidaknya meliputi peliburan sekolah dan tempat kerja, pembatasan kegiatan keagamaan, dan pembatasan kegiatan di tempat atau fasilitas umum (Kompas, 2020). 
Sedangkan Karantina Wilayah merujuk pada Undang-Undang Nomor 6 tahun 2018 Pasal 1 Ayat 10 Tentang Karantina Kesehatan yang menyebutkan bahwa "Karantina wilayah adalah pembatasan penduduk dalam suatu wilayah termasuk wilayah pintu masuk beserta isinya yang diduga terinfeksi penyakit dan/atau terkontaminasi sedemikian rupa untuk mencegah kemungkinan penyebaran penyakit atau kontaminasi." Karantina wilayah dilaksanakan kepada seluruh anggota masyarakat di suatu wilayah apabila terjadi penyebaran penyakit di wilayah tersebut; wilayah yang di karantina diberi garis karantina dan dijaga terus-menerus oleh pihak kesehatan dan kepolisian yang berada di luar wilayah karantina; anggota masyarakat juga tidak diperkenankan untuk keluar masuk wilayah karantina. Hal yang ditekankan dari Pasal 55 adalah pemerintah pusat bertanggungjawab memenuhi kebutuhan pokok masyarakat bahkan makanan untuk hewan ternak selama karantina wilayah; Tanggung jawab pemerintah pusat melibatkan pemerintah daerah dan pihak terkait dalam menerapkan karantina wilayah. ${ }^{22}$

Perdebatan urgensi karantina wilayah atau PSBB yang menjadi kewenangan pemerintah pusat perlu disesuaikan dengan pemerintah daerah, karena tidak semua daerah di Indonesia memiliki kapasitas yang sama. Jakarta bisa saja menerapkan PSBB tetapi belum tentu bisa secara efektif diterapkan di Indonesia Timur. Koordinasi pusat dan daerah yang menentukan apakah suatu daerah pantas karantina wilayah tidak (yang penerapannya dapat parsial), karena perlu menyesuaikan dengan kebutuhan dan kapasitas daerah. Terciptanya decision making didukung dengan hilirisasi yang sepadan. Upaya transparansi cepat tanggap sampai sejauh ini justru terlihat dari sejumlah pemerintah daerah yang menetapkan kebijakan publik secara mandiri.

Mengingat kembali bahwa kebijakan publik erat kaitannya dengan pelayanan dari pemerintah kepada masyarakat. Di Indonesia, prinsip transparansi untuk mewujudkan good governance dan mendukung kebijakan pemerintah tertuang dalam Undang-Undang Nomor 25 Tahun 2009 Pasal 4. Partisipasi masyarakat berperan krusial dalam mengawasi pelayanan masyarakat. Penyelenggaraan negara diwujudkan melalui keterbukaan politik sebagaimana tertuang dalam UU Nomor 14 Tahun 2008 tentang pentingnya keterbukaan publik dalam rangka mewujudkan partisipasi dan penyelenggaraan negara yang transparan, efektif, efisien, dan akuntabel. ${ }^{23}$ Sistem good governance utamanya dalam poin transparansi yang diidam-idamkan masyarakat dunia hari ini masih menjadi polemik dalam kebijakan publik. Decision making dalam kebijakan publik sebagai strategi nasional dunia hari ini harus disadari bahwa hal yang kerapkali membenturkan adalah antara kebutuhan, pemahaman, dan yang seharusnya.

\section{Kesimpulan}

Transparansi dalam sistem good governance dalam penanggulangan pandemi COVID-19 di berbagai belahan dunia menjadi kunci keberhasilan sejumlah pemerintah di dunia. Keterbukaan informasi, ketepatan mobilisasi, koordinasi pemerintah pusat

22 Akbar Bhayu Tamtomo. (2020). Infografik: Beda PSBB dengan Karantina Wilayah. Diakses dari https://www.kompas.com/tren/read/2020/04/01/180300065/infografik-beda-psbb-dengan-karantinawilayah

$$
{ }^{23} \text { Op.Cit. }
$$


dan daerah, serta partisipasi masyarakat yang solid menjadi dukungan inti bagi terlaksananya kebijakan publik yang efektif. Kebijakan publik yang efektif akan mampu menjadi strategi nasional yang dapat menekan kasus penularan COVID-19.

\section{Referensi}

A National Strategy on AIDS. (1989). Issues in Science and Technology Volume 5(3) hlm. 52-59. Diakses dari www.jstor.org/stable/43309389

Aftergood, Steven. (2019). Transparency vs. Good Government. Diakses tanggal 28 Maret 2020, dari https://fas.org/blogs/secrecy/2019/11/transparency-vs-goodgovt/

Alexander, Hilda. (2020). Sekali Lagi, Ini Rahasia China Bangun Rumah Sakit Corona Secepat Kilat. Diakses dari https://properti.kompas.com/read/2020/02/04/063000521/sekali-lagi-ini-rahasiachina-bangun-rumah-sakit-corona-secepat-kilat?page=all

Bauhr dan Grimes. (2012). What is Government Transparency? New Measures and Relevance for Quality of Government. Diakses dari University of Gothenburg, https://qog.pol.gu.se/digitalAssets/1418/1418047 2012 16 bauhr_grimes.pdf

Brau, Andres Sanchez. (2020). Commitment, Transparency Pay Off as South Korea Limits COVID-19 Spread. Diakses dari https://www.euractiv.com/section/coronavirus/news/commitmenttransparency-pay-off-as-south-korea-limits-covid-19-spread/

Chung dan Soh. (2020). Korea's response to COVID-19: Early Lessons in Tackling the Pandemic. Diakses dari https://blogs.worldbank.org/eastasiapacific/koreasresponse-covid-19-early-lessons-tackling-pandemic

Duff-Brown, Beth. (2020). How Taiwan Used Big Data, Transparency and a Central Command to Protect Its People from Coronavirus. Diakses dari Stanford University https://fsi.stanford.edu/news/how-taiwan-used-big-datatransparency-central-command-protect-its-people-coronavirus

Dzulfaroh, Ahmad Naufal. (2020). Mengenal Leishenshan, Rumah Sakit Kedua Khusus Virus Corona. Diakses dari https://www.kompas.com/tren/read/2020/02/06/104500265/mengenalleishenshan-rumah-sakit-kedua-khusus-virus-corona?page $=2$

Fleming, Sean. (2020). Viet Nam Shows How You Can Contain COVID-19 with Limited Resources. Diakses dari https://www.weforum.org/agenda/2020/03/vietnamcontain-covid-19-limited-resources/

Fung, Graham, Wil, Fagotto. (2007). Transparency Policies: Two Possible Futures. Diakses dari Harvard University, https://www.hks.harvard.edu/sites/default/files/centers/taubman/files/transpar ency new.pdf 
Leblanc, Daniel. (2020). Trudeau Vows Better Gathering and release of Pandemic Data. Diakses dari https://www.theglobeandmail.com/politics/article-trudeau-vowsbetter-gathering-and-release-of-pandemic-data/

Nguyen, Kai. (2020). Quarantined in Vietnam: Scenes from Inside a Center For Returning Citizens. Diakses dari https://www.npr.org/sections/pictureshow/2020/04/06/823963731/quarantinedin-vietnam-scenes-from-inside-a-center-for-returning-citizens

Palanithurai, G. (2005). Good Governance at Grassroots. The Indian Journal of Political Science, 66(2) hlm. 289-312. Diakses dari www.jstor.org/stable/41856129

Qiu, Rutherford, Mao, Chu. (2016). The Pandemic and Its Impact. Health, Culture, and Society. Volume 9-10 (2016-2017). Hlm. 3-5. Diakses di https://www.researchgate.net/publication/321689453 The Pandemic and its I $\underline{\text { mpacts }}$

Relly and Sabharwal. (2008). Perceptions of Transparency of Government Policymaking: A Cross-national Study. Government Information Quarterly Volume 26(1): 148157. DOI: $\underline{10.1016 / j . g i q .2008 .04 .002}$

Rochester Regional Health. (2020). Pandemic vs. Epidemic: What's the Difference?. Diakses tanggal 28 Maret 2020, dari https://www.rochesterregional.org/news/2020/03/pandemic-vs-epidemic

Tamtomo, Akbar Bhayu. (2020). Infografik: Beda PSBB dengan Karantina Wilayah. Diakses https://www.kompas.com/tren/read/2020/04/01/180300065/infografik-bedapsbb-dengan-karantina-wilayah

Septiani, Maya. (2020). Strategi Mewujudkan Transparansi dan Partisipasi dalam Pelayanan Publik. OMBUDSMAN, Diakses dari https://ombudsman.go.id/artikel/r/artikel--strategi-mewujudkan-transparansidan-partisipasi-dalam-pelayanan-publik

Seesaghur, Hans Nibshan. (2015) Good Governance with Chinese Characteristics: A Perspective of China's Socialist Model. Journal of Public Administration and Governance 2015, Volume 5 Nomor 3. DOI: 10.5296/ jpag.v5i3.8028

UNODC. (2007). National Strategy on Increasing Transparency and Anti-Corruption 2007-2011. Diakses dari https://www.unodc.org/documents/corruption/Best $\% 20$ Practices/Azerbaijan $\% 2$ 02007-2011Strategy\%20Expl\%20Note-Eng.pdf

World Healt Organization. (2020). Report of the WHO-China Joint Mission on Coronavirus Disease 2019 (COVID-19). Diakses dari https://www.who.int/docs/default-source/coronaviruse/who-china-jointmission-on-covid-19-final-report.pdf 
Upadhayay, Videvh. (2004). Good Governance as a Right. Economic and Political Weekly Volume 39, No. 16 (Apr. 17-23, 2004) hlm. 1631-1632. Diakses dari https://www.jstor.org/stable/41856129?seq=1

Town, Jenny. (2020). South Korea's Pandemic Response. Diakses dari https://www.stimson.org/2020/south-koreas-pandemic-response/

USAID. (2013). Transparency and Accountability: Regional Agricultural Trade Environment (RATE) Summary. USAID Regional Development Mission for Asia. Diakses dari https://www.usaid.gov/sites/default/files/documents/1861/Transparency and Accountability.pdf

https://ballotpedia.org/Government transparency

https://www.icmm.com/en-gb/society-and-the-economy/governance-and-transparency

https://www.ft.com/content/0cc3c956-6cb2-11ea-89df-41bea055720b 


\section{Indexed by :}
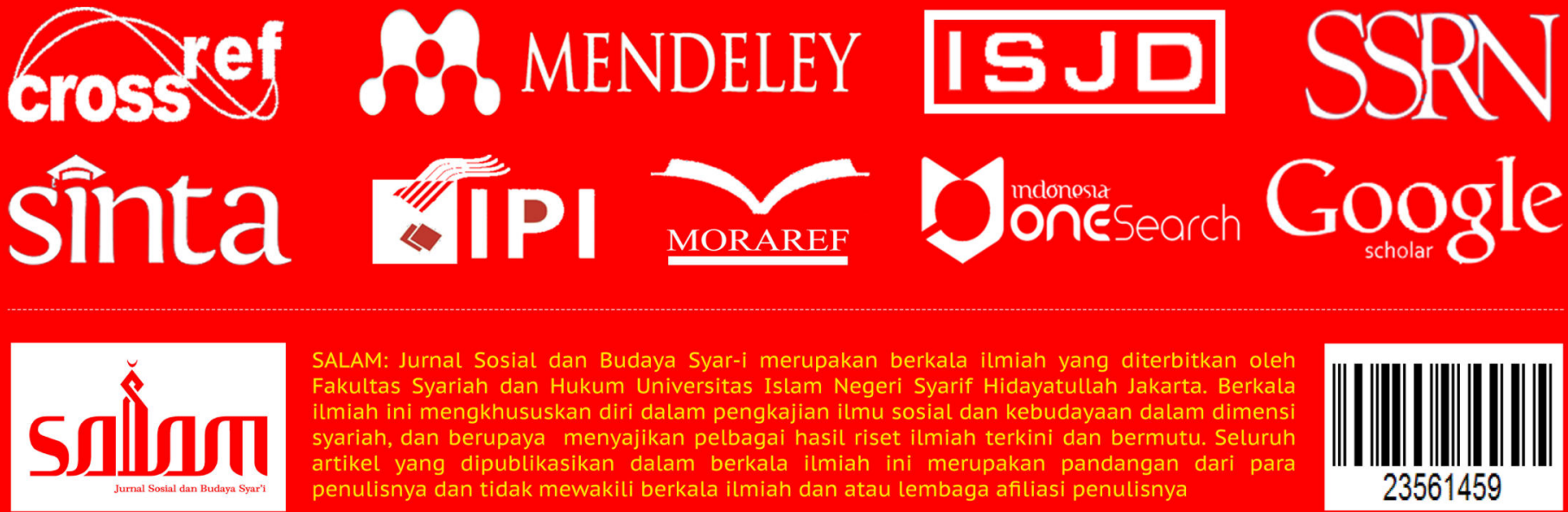

SALAM: Jurnal Sosial dan Budaya Syar-i merupakan berkala ilmiah yang diterbitkan oleh Fakultas Syariah dan Hukum Universitas Islam Negeri Syarif Hidayatullah Jakarta. Berkala ilmiah ini mengkhususkan diri dalam pengkajian ilmu sosial dan kebudayaan dalam dimensi syariah, dan berupaya menyajikan pelbagai hasil riset ilmiah terkini dan bermutu. Seluruh artikel yang dipublikasikan dalam berkala ilmiah ini merupakan pandangan dari para penulisnya dan tidak mewakili berkala ilmiah dan atau lembaga afiliasi penulisnya

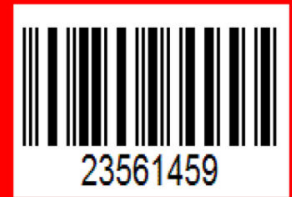

